Bangladesh J. Plant Taxon. 17(2): 203-207, 2010 (December)

(c) 2010 Bangladesh Association of Plant Taxonomists

\title{
NITELLOPSIS OBTUSA (DESV.) J. GROVES : A NEW CHAROPHYTIC RECORD FOR BANGLADESH
}

\author{
SABRina NAZ ${ }^{1}$, NASRin Jahan Diba AND M. Zaman \\ Department of Botany, University of Rajshahi, Rajshahi 6205, Bangladesh \\ Keywords: Nitellopsis obtusa; Characeae; New record; Bangladesh.
}

Hy established Nitellopsis Hy as a genus in 1889. Nitellopsis obtusa (Desv.) J. Groves was described as Chara obtusa in 1809 by Desvaux. This genus includes three species, viz., N. obtusa (Desv.) J. Groves, N. bulbifera C. Dont. and N. sarcularis Zaneveld (Wood and Imahori, 1965). Nitellopsis obtusa (Desv.) J. Groves, a macroalga is widespread throughout Europe and Asia from Scandinavia to Japan. Kundu (1929) initiated Charophyte research in the then East Pakistan (now Bangladesh). Then the Charophyte flora has been worked out by Kundu (1938), Agharkar and Kundu (1937), Islam and Sarma (1976), Zaman (2001), Aziz and Tanbir (2003) and Naz and Diba (2009). So far, four genera, namely Chara, Nitella, Lychnothamnus and Lamprothamnium have been described from different parts of Bangladesh. In the present investigation the genus Nitellopsis Hy and its species Nitellopsis obtusa (Desv.) J. Groves has been recorded for the first time in Bangladesh.

The plant materials were collected from a shallow water zone (10 cm depth of water) of the river Mahananda of Chapai-Nawabganj district. Fresh materials were freely displayed on a petridis with distilled water and photomicrographs were taken by SONY DSC W-55 under compound microscope (Model L-101). Specimens have been kept in the herbarium of Phycology and Limnology Laboratory, Department of Botany, University of Rajshahi, Bangladesh and also preserved in Transeau`s solution (Transeau, 1951). Camera Lucida drawings were made at 25x, 50x, 60x, 100x and 150x magnifications. Air temperature and relative humidity of the sampling location were measured by a digital thermometer and a humidity meter (Model: HANNA), respectively.

Nitellopsis obtusa (Desv.) J. Groves, Jour. Bot. 57: 127. 1919. [Chara obtusa Desvaux in Loiseleur-Deslongchamps, Not. Pl. Fl. France, p. 136. 1810. Nitellopsis stelligera (Bauer) Hy, Rev. Bot. 8: 46. 1890.] (Pl. 1, Figs A-L; Pl. 2, Figs 1-10)

(Groves and Webster 1924, 3, Pl. 24, Figs. 1-8; Pal et al. 1962, 80, Figs. 171-175; Krause 1997, 128, Fig. 50: A-I; Langangen et al. 2002, 30, Fig. 20; Schubert and Blindow 2003, 216, Fig. 4.28.1: A-J).

Common name: Starry stonewort.

'Corresponding author. E-mail: drsabrina_naz@yahoo.com 
Plant dioecious, upto $14 \mathrm{~cm}$ high, not incrusted, deep green, lower axial nodes white, stellate; plant entirely ecorticate; stem slender, up to $458 \mu \mathrm{m}$ in diameter; stipulodes absent; branchlet up to $2 \mathrm{~cm}$ long; internodes up to $4 \mathrm{~cm}$ long; branchlet 5-7 in a whorl,

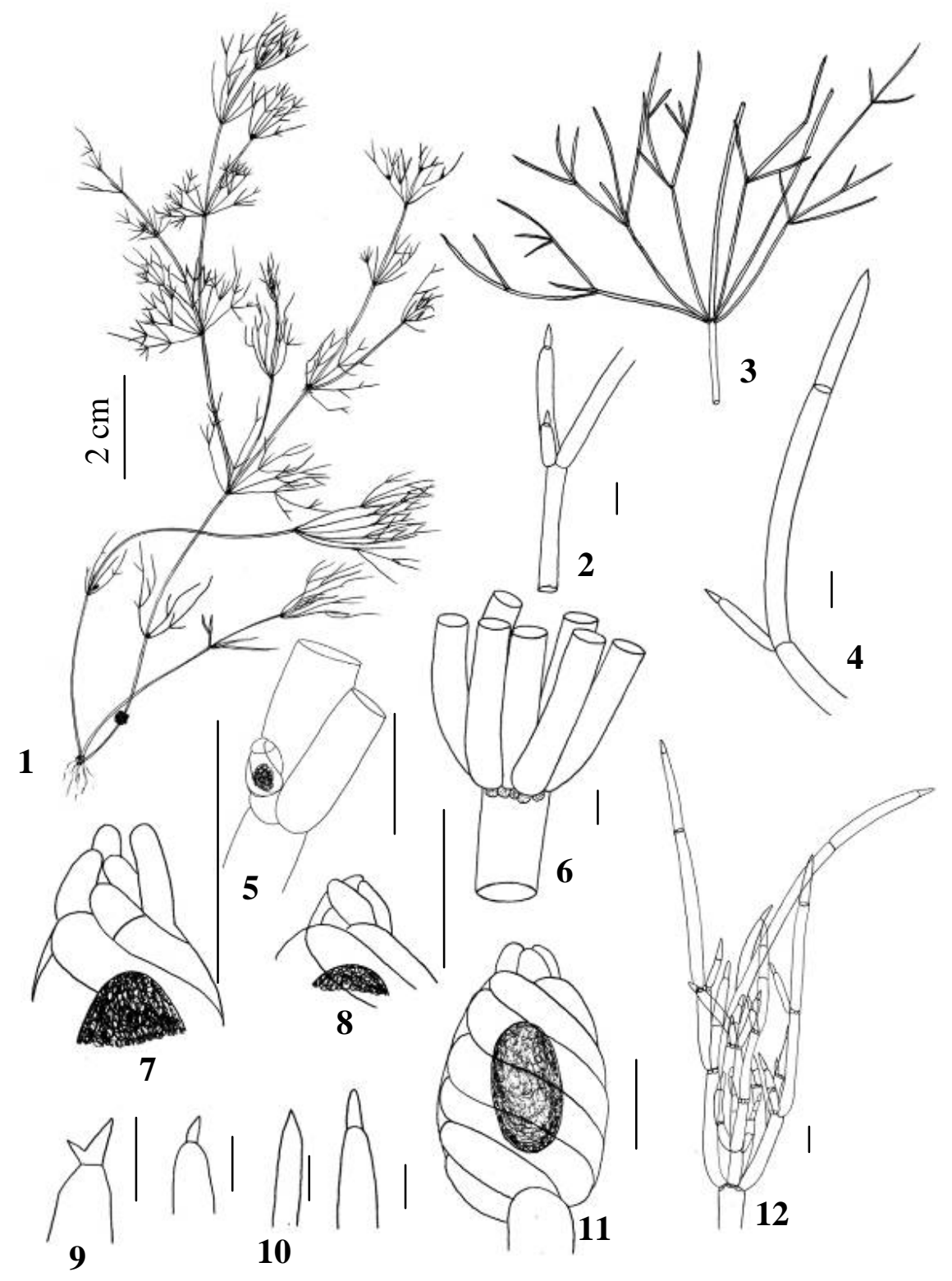

Figs. 1-12. Nitellopsis obtusa (Desv.) J. Groves.1. Habit; 2. Bract cells; 3. A whorl; 4. Upper portion of a branchlet and bract cells; 5. A branchlet node and oogonium; 6. Stem node; 7, 8. One tier corona; 9. Bifid end cell (aberration); 10. End cells (acuminate-mucronate); 11. Oogonium; 12. A young whorl. (Scales $=0.2 \mathrm{~mm})$. 
straight, incurved (above), reflexed (below), segments 2-3, elongate; end segment 1-2 celled, cylindrical; end cell short, conical, acuminate-mucronate; bract cells 2-4, conical, sometimes absent, cylindrical, resembling the end segment of branchlets; oogonium solitary, egg-shaped, $500 \mu \mathrm{m}$ long (including corona), $343 \mu \mathrm{m}$ wide, convolutions 6-9; corona small, one tier, rarely elongate, 43-72 $\mu \mathrm{m}$ long, 57-72 $\mu \mathrm{m}$ wide at base; oospore $286 \mu \mathrm{m}$ long, $272 \mu \mathrm{m}$ wide (plant richly fertile but ripe oospores were not found); antheridium (male plant) not found. Bulbils white, stellate.
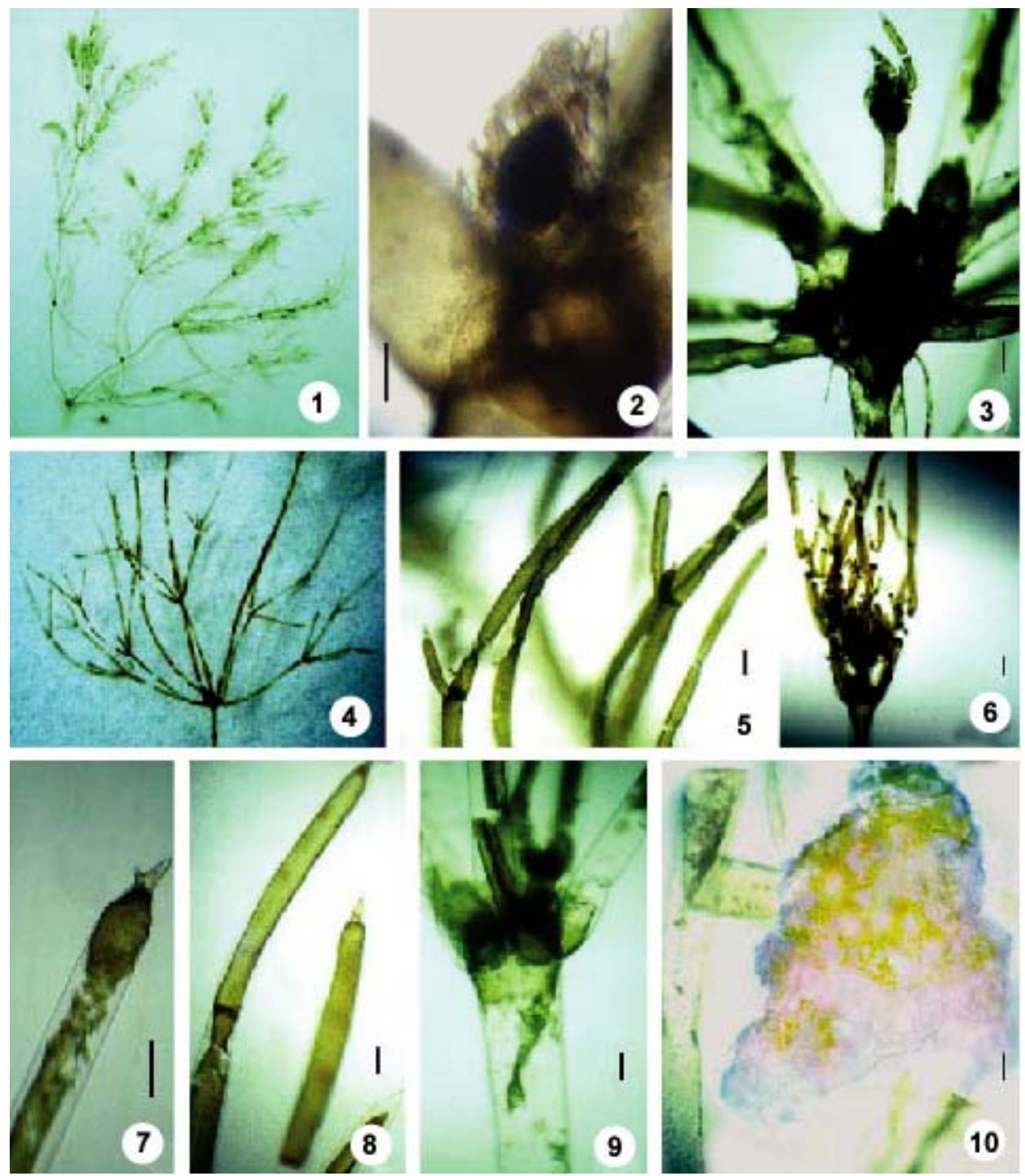

Plate 2. Nitellopsis obtusa (Desv.) J. Groves 1. Habit; 2. Oogonium; 3. New shoot arising from stem node; 4. A whorl; 5. Bract cells; 6. A young whorl; 7. Bifid apices of branchlet; 8. Apices of branchlet; 9. Stem node; 10. Bulbil. (Scales= $0.2 \mathrm{~mm}$ ). 
Specimen examined: Chapai-Nawabgonj, Mahananda river, 15.03.2004, Nasrin Jahan Diba Col. No.1.

Ecology: Freshwater lotic habitat (river) with sandy bottom at $10 \mathrm{~cm}$ depth of water. This plant was found from a depth of about $1500 \mathrm{~m}$ from Dhal lake in Kashmir (Pal et al., 1962). Existing literature further reveals Nitellopsis obtusa is a species which often is found in deep water, from 1-8 m; mainly found in freshwater but also in brackish water in the Baltic Sea.

Distribution: Nitellopsis obtusa is mainly distributed in Europe but occasionally it is found in Asia and Africa including India, Pakistan, Myanmar, Malaysia, Japan and Iraq.

Notes: Nitellopsis obtusa does not often produce oospores and vegetative reproduction by star-shaped bulbils is therefore important. Fructification is very low for this species and ripe oospores are rarely found. During the present study ripe oospores were not observed. Fructification is in July-October and is dependent on light intensity (Langangen, 2007). Schubert and Blindow (2003) state that antheridia are occasionally found in Nitellopsis obtusa, however, in the present investigation, we did not find antheridia. The plant resembles Nitella translucens (Pers.) Agardh but there is no terminal branchlet corona in Nitellopsis obtusa and by contrast there are no bract-cells or bulbils in Nitella translucens (Wood and Imahori, 1965). The species is easily recognizable by means of its bulbils, which in the examined material are common on most nodes, but best developed on the lower nodes.

\section{References}

Agharkar, S.P. and Kundu, B.C. 1937. Charophytes of Bengal. J. Dep. Sci. Calcutta Univ. N. S. 1(1): 1-23.

Aziz, A. and Tanbir, M. 2003. Algal flora of some northern districts of Bangladesh. Bangladesh J. Plant Taxon. 10(1): 63-78.

Groves, J. and Webster, G.R.B. 1924. The British Charophyta. Vol. II. Chareae with plates, concluding articles, geological sketch, bibliography and index. Ray Society, London. pp. 3-6.

Islam, A.K.M.N. and Sarma, D. 1976. The Characeae of Bangladesh II. Genus Nitella. J. Asiat. Soc. Bangladesh (Sci.) 2(1): 43-61.

Krause, W. 1997. Charales (Charophyceae). Süsswasserflora von Mitteleuropa. Band 18.Gustav Fischer Verlag. pp. 128-131.

Kundu, B.C. 1929. Studies of the Charophytes of Bengal. Pt. I. Proc. Indian Sci. Congr. p. 248.

Kundu, B.C. 1938. A new Nitella from Rajshahi, Bengal. J. Indian Bot. Soc. 16: 223-226.

Langangen, A. 2007. Charophytes of the Nordic countries. Saeculum. ANS. 102 pp.

Langangen A., Koistinen, M. and Blindow, I. 2002. The Charophytes of Finland. Memoranda Soc. Fauna Flora Fennica 78:17-48.

Naz, S. and Diba, N.J. 2009. Genus Lamprothamnium J. Groves. In: Ahmed, Z.U., M. Khondker, Z.N.T. Begum, M.A. Hasan, S.M.H. Kabir, M. Ahmed, A.T.A. Ahmed and A.K.A. Rahman (eds). Encyclopedia of flora and fauna of Bangladesh. Algae, Charophyta-Rhodophyta. Asiatic Society of Bangladesh, Dhaka 4:13. 
Pal, B.P., Kundu, B.C., Sundaralingam, V.S. and Venkataraman, G.S. 1962. Charophyta - Monographs on Algae, Vol. 5. Indian Council of Agricultural Research, New Delhi. pp. 80-81. Indian Council of Agriculture Research, India.

Schubert, H. and Blindow, I. 2003. Charophytes of the Baltic Sea. A.R.G. Gantner Verlag, Ruggell. pp. 216222.

Transeau, E.N. 1951. Periodicity of fresh water algae. Amer. J. Bot. 3: 121-133.

Wood, R.D. and Imahori, K. 1965. A revision of the Characeae. Part-I. Monograph of the Characeae. Verlag Von, J. Cramer, Weinheim. pp. 349-355.

Zaman, M. 2001. Assessment of diversity of algal flora in Chalan beel in relation to physico-chemical conditions. In: Survey of flora National conservation strategy (NCS) Implementation project-1, Ministry of Environment \& Project, Government of the People`s, Republic of Bangladesh. pp. 194-212

(Manuscript received on 5 August, 2009; revised on 22 November 2010) 